\title{
The fading of disaster memory in Pulau Sebesi: A historical construction
}

\author{
Devi Riskianingrum ${ }^{1, *}$ and Herry Yogaswara ${ }^{2}$ \\ ${ }^{1}$ Department of History, Faculty of Humanity, University of Indonesia \\ ${ }^{2}$ Research Centre for Demography, Indonesian Institute of Sciences
}

\begin{abstract}
The island has been impacted by volcanic eruptions which led to tsunami in a different scale, where in 1883 claimed 36000 lives, subsequently in 2018 took one victim. Some island communities succeed in pertaining memory of tsunami through oral tradition, namely Simeulue, differently Sebesi communities fail to maintain its memory on tsunami. The gap of 138 years seems to bury the memory of tsunami in Sebesi island. This paper aims to explore why the Sebesi communities fail to maintain the disaster memory. To build an understanding the way in which the Sebesi forgetting their past disaster, this paper uses longue durée approach, oral history framework and archival studies to analyses the structures - both environmental structures and socio-politic and cultural structuresthat play roles in the disappearance of disaster memory. The study revealed that none of survivor during its catastrophic tsunami in 1883 and repopulation of this island occurred only after 1940s. This resulted to the formation of community without disaster memory. Only after the 2018 tsunami, the community of Sebesi Island began to aware that there are hazards among their environments. Uncovering the fading of disaster memory in Pulau Sebesi elucidates lessons to pursue resilient development trajectory on the island.
\end{abstract}

\section{Introduction}

“...every full moon I feel frightened Remember the high waves chasing our vessel. If only it rolled over our vessel, I may be death by then ..." (Bapak Jefry-eyewitness and survivor of 2018 tsunami/ a staff of BKSDA Lampung). The tsunami disaster that occurred on December 22, 2018, at around 21:27 WIB, exhibited an important value for the people of Sebesi Island. The disaster that stricken during the full moon killed 430 people in the Pandeglang area and the coast of South Lampung [1]. It became a milestone for a disaster awareness of the people in Sebesi on the dangers of their surrounding environment.

PVMBG (Volcanology and Geological Disaster Mitigation Center) has been monitoring this mountain since early December 2018. The agency detected an increase in eruption activity of Anak Krakatau on Friday, December 21, 2018, with a throw height reaching 738 meters above sea level. Therefore, Anak Krakatau received an alert status from this institution. In line with this, BMKG (Meteorological, Climatological, and Geophysical Agency) also monitored the threat of high waves on December 22 and gave warnings to the public [2]. Unwittingly, continuous eruption since early

\footnotetext{
* Corresponding author: devichudori@gmail.com
}

December triggered landslides on the slopes of Anak Krakatau. According to research, an area of 64 hectares of the southwest slope of Anak Krakatau experienced a landslide on Saturday at 20:56 WIB, hence generated tsunami [3].

Sebesi Island located only $20 \mathrm{KM}$ or 10.8 nautical miles from Anak Krakatau also hit by the tsunami. This led the island dealt with communication paralyze and isolation, hence caused panic from around 2700 residents living in Sebesi. The help from rescue team came a day after the tsunami due to high waves. The government also helped evacuate the residents of Sebesi to Kalianda, South Lampung. Based on observations, there were about 50 houses in Regahan Lada Hamlet that were destroyed. However, it claimed only one victim, a child of a seasonal worker from Pandeglang who at that time stayed in Gubuk Seng area in Sebesi island. The 5-year-old toddler was separated from his parents' grip and swept by the waves [4]. Instead of evacuated to Kalianda, some residents prefer to stay on the island to protect their property and they belief that Anak Krakatau will soon get better. Until now, the Sebesians opt to stay in the island with various reasons, from assets to livelihoods that are easier to find on Sebesi Island [5]. It seems that they have anchored their life in Sebesi, where they spend their live and die with the island. 
For the people of Sebesi, the 2018 tsunami disaster appeared to be a new experience, although history recorded a similar disaster with larger scale had hit this island. The eruption of Mount Krakatau on August 27, 1883 was so intense that it generated a tsunami and devastated the coasts of Pandeglang, South Lampung, and Sebesi Island, and even affected the world [6]. The span of 138 years has succeeded in fading the disaster memory in the minds of Sebesians. Although, on other affected area like in Labuan sub-district, Pandenglang, the communities continue to commemorate the calamity by convening haul kalembak, a tradition where people gathered in Labuhan Great Mosque to pray for the victims of Krakatau 1883. In addition, the people of Simeulue island were able to preserve the experience of the tsunami disaster that had befallen them in 1907. Through oral tradition, namely lullaby and storytelling, the experience was recorded and continued to be conveyed to the younger generation of this island community. The tradition, known as smong, proved to save the people of Simeulue island from the great tsunami in 2004 [7].From a historical perspective, Bankoff [8] explains that disasters can be seen in two trajectories, namely 'natural'-in this case the forces of nature - on the one hand, and society on the other. When these two trajectories meet at a certain place and time, a catastrophic event occurs. At that time a new experience is formed for the survivors. The experience of individual will form a shared memory in a particular community. This is in line with Halbwach's explanation which states that collective experiences could form into 'collective memory.' He explains that memory refers to individual processes, but it has a role in constructing "collective memory" within the community by forming specific behaviour limited to specific communities, location, certain area, and time [9]. He concluded that a shared framework for a memory is a result or combination of individual's memory from people in the same community [10]. Based on this concept, the paper tries to reconstruct the failure of the Sebesi community in preserving the memory of tsunami Krakatau in 1883. Furthermore, new knowledge that emerged after the 2018 tsunami as a form of new behaviour in the Sebesi community will also be analysed.

\section{Methodology and research sites}

This paper aims to reconstruct the fading of tsunami 1883 memory on the people of Sebesi island. Further, it also analyses the new knowledge arise as an impact of the recent tsunami. To have broader understanding about collective memories and how people maintained it, this paper applies limited comparative case study with local knowledge of Smong from Simeulue of Aceh [7], [11], [10]. It is the knowledge that attracted many scholars to study and translated into policy implementation.
This research employed longue durée approach with archival study and oral history. Longue durée is a structural analysis of historical reality without leaving the aspect of time in it, which presupposes structural change itself, although it runs very slowly. It is not always referring to temporalities, but rather a way of seeing reality that is formed slowly over a long period, which then becomes a precondition for the problems that arise on the surface. This approach enables to find the relationship between agency and environment over the long period of time. The slowmoving time that running in a long process becomes the precondition of fast-moving time as conjuncture, which later comes to the surface as an event [12]. Accordingly, the change of community structure as the result of natural structure recorded in the memory could be investigated throughout the approach.Primary data and secondary information presented in this paper were gathered during irregular visits to Sebesi island for several weeks in 2019, 2020, and 2021. Data were gathered through archival studies, literature reviews, and interviews with older individuals and tsunami survivors that they remember, in search of stories about disasters in this island. Secondary data were gathered from the Internet and published reports. Academic papers, as well as relevant documents of governmental and non-governmental organizations, were studied and evaluated. Some relevant reviews of selected literature and published stories about earthquakes and tsunamis were also analysed and elaborated in this paper. In addition, a field notes of a project conducted by Indonesian Institute of Sciences in some coastal areas of Banten in 2015 related to Risk Culture is using in this paper to enrich knowledge about people and disaster in coastal area.

Sebesi Island is in Lampung Bay with coordinates at the position of $05^{\circ} 055^{\prime} 37.43^{\prime \prime}$ $05^{\circ} 058^{\prime} 44.48^{\prime \prime}$ South Latitude and $105^{\circ} 027^{\prime} 30.50^{\prime \prime}-$ $105^{\circ} 030^{\prime} 47.54^{\prime \prime}$ East Longitude. It has an area of 2620 hectares, currently there are 787 families or about 2795 people recorded living on the island. For livelihood, most of the people in Sebesi work as farmers as much as $75 \%$, and fishermen as much as $20 \%$, and $5 \%$ consists of government employees, traders, and tourism actors. Meanwhile, the dominant ethnic group on this island is Banten (Javanese-Serang or Jaseng), while the second largest ethnic group is South Lampung, and several other ethnic groups such as Sundanese, Batak, Nusatenggara, Bugis, and Padang [13].

Sebesi island is bordered by Lampung Bay and Sebuku Island in the north, the Indian Ocean in the west, the Krakatau Island complex-including Mount Anak Krakatau - in the south, and the Sunda Strait in the east. Based on its administration, Sebesi island is included in the administrative area of Tejang Village, Rajabasa District, South Lampung Regency. In Tejang Village, there are four hamlets, namely Hamlet I Bangunan, Hamlet II Inpres, 
Hamlet III Regahan Lada, and Hamlet IV Segenom [14].

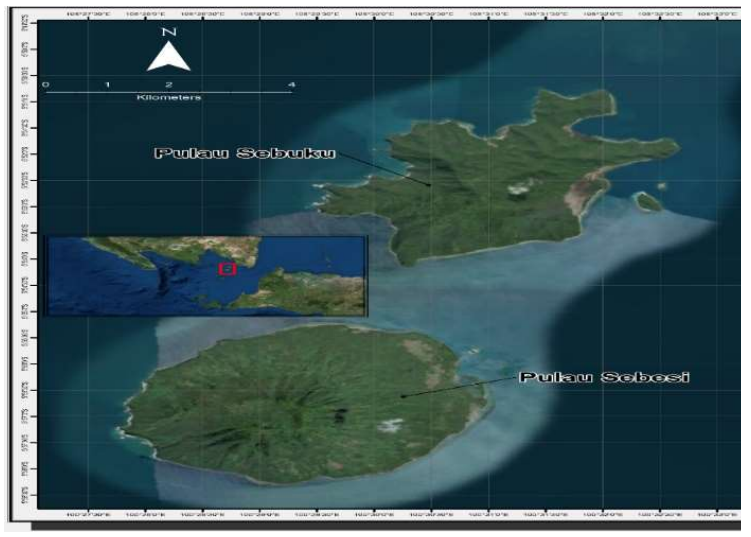

Fig.1 The map of Sebesi Island.

Source: Biologi LIPI 2019

\section{Result and discussion}

\section{1 The Dynamics of post-tsunami 1883 in Sebesi Island: from Plantation to Settlement and Tourism}

Although it is obscure in the Dutch archives, the Sebesi island's fertility has lured the people to settle, both those who came from around the Rajabasa and Kaimbang areas, as well as those who came from Banten. Long before Krakatau erupted, this island had become a stopover for Dutch ships before entering the Banten waters. If the English ships with their weapons and merchandise were to land on Legoendi Island, then the Dutch ships, one of which was commanded by Pieter de Carpentier in 1624, had a place on Sebesi Island to fill water and supplies, repair the ship, and wait for permission to enter the Port of Banten [15].

After the eruption of Krakatau, Sebesi island became uninhabited. The first visit to Sebesi was 14 days after the eruption. It was conducted by Berg from Javabode in 1883 described that this island buried with 6 meters thick mudbank and giant pumice stone along the shore [16], [17], [18]. Another visit on May 21, 1884, explained that living creature was only consisted of a few banana treetops, tall weed, and bushes and full of desolation. The atmosphere of the island was only a stretch of white sand and bones - which was unknown whether they were animal or human bones [19].

After the eruption of Krakatau, the ownership of the Sebesi island was on dispute due to the death of all the descendants of Pangeran Singa Brata and all existing evidence of ownership. Pangeran Minak Poetra claimed to be the younger brother of the remaining Pangeran Singa Brata and appealed for these two islands. According to the customary law, since all the descendants of Singa Brata have become victims of Krakatau, hence Minak Poetra, as a younger brother, can be appointed as head of the Raja Basa clan or penyimbang. He also appointed himself as Bandar, that traditionally with this position has power over these islands. The appointment of Minak Poetra's also received the blessing from the Sultan of Banten in the 1890s [20].

Furthermore, the Dutch also approved Minak Poetra as a penyimbang as well as bandar of Raja Basa. This is known from his action in giving assistance to the Dutch to cease the rebellion in Cilegon-Banten in 1888. Furthermore, the Dutch approval was also seen as an effort to cut off the descendants of Pangeran Singa Brata. He was known as important ally of Radin Inten II's in struggling against the Dutch. In the hands of Minak Poetra, Sebuku island was initially leased to a Lanberg firm in 1889 to grow pepper and timber, while Sebesi was left to remain. Subsequently, Sebesi and Sebuku Islands were sold to the trader named Hadji Djamaloedin in 1896. He and Pangeran Minak Poetra were awarded a gold medal from the Dutch government in 1888 for helping to stop the riots in Cilegon. Sebesi island was purchased for f.7000 while Sebuku was priced at f.3000. under Djamaloedin, these two islands obtained the status of individueel bezight recht (private property/goods) through the Governor General's besluit in 1906 [21], [22].

\section{Plantation}

As if a blessing in disguise from Krakatau eruption 1883 , the land on Sebesi became very fertile so that the agricultural products of this island were abundant. A report on a trip to Sebesi island in the 1920 s stated that the island was filled with thriving coconut trees planted by $\mathrm{Hj}$ Djamaloedin and his workers. An archive states that a ship loaded with chickens and goats was sent from Kalianda port to Sebesi island by Hj. Djamaloedin in the early 1900s and was followed by the dispatch of workers from Banten to Sebesi [23].

Entering the 1940s, the world economic conditions declined and were overshadowed by the threat of the second world war. This influenced the economic condition on Sebesi. Coconut prices have fallen quite badly. In the era of the 1950s, coconut prices improved again and gave decent results. This evidenced by several supervisor who went to hajj from the sales of coconuts at that time [24].

As the coconut continues to support Sebesi's economy, bananas have also become an important commodity on this island. Bananas became staples food for the community since it always available in the island. In line with this, this island once became a shot of clove cultivation in 1990s. Some farmers change their gardens by planting cloves. This commodity was destroyed during the 1997 monetary storm, and residents began destroying clove trees and replacing them again with coconut and bananas. 
In 2004, the government came up with a cocoa planting program. Unfortunately, without market clarity, the results of chocolate in Sebesi are not as sweet as expected. Today, society continues to focus on coconut-which is sold in the form of granules for one thousand rupiah per grain - and bananas, as the main commodities to support their lives [25].

\section{Settlement}

The development of settlements on this island is closely related to plantation activities. The first wave was in the 1920s, where most of them were farmers from the Canti, Way Muli and surrounding areas also came to ask Hadji Djamaloedin's permission to open agricultural land. Later, the waves of workers that brought by the land owner also opted to settle in the island during 1930s. They were allowed to farm with a profit-sharing system, where $2 / 3$ is owned by the farmer and $1 / 3$ is given to the owner of the island. The results that are shared were not in the form of commodities, in this case coconut, but $1 / 3$ of the total trees grown by the farmer [26].

Like their fellow farmers, these workers also applied for approval to work on a piece of land with profit-sharing system. The requests were granted by Hadji Djamaloedin and this system was continued by his son, Saleh Ali. Since 1937, Saleh Ali issued a letter of agreement with several laborers who asked to become cultivators with a profit-sharing system. Entering the 1940s, these workers brought their families with them, and began to build an umbul (like a small hamlet) consisting of several houses from fellow workers. In this era, the island of Sebesi returned to a settlement for the workers community [27].

In other part, the waters where Mount Krakatau used to stand showed its seismic and volcanic activities in 1927. The roar and large bubbles rise to the surface, erupted and release ash and sulfuric gas. These bubbles were an indication that it was an effort of a new mountain to build itself. On January 26,1928 , a pile of ash and solid rock began to emerge from the sea in a shape of a curve. This was followed by explosive and earthquake activities which continued until 1929. The solid rock began to grow into a new black plain and continued to expand to form an island. It was a Russian geophysicist, W.A Petroeschevsky, who first noticed this condition and observed it closely from Panjang Island. He named this nascent plain as 'Child of Krakatau.' The island began to show its stability on August 11, 1930, and further solid growth in the 1931 [6]. In response to this, the colonial government carried out detailed observation on the growth of this newly born mountain. A monitoring post in Kalianda was also obliged to report to the central government in Buitenzorg about daily condition of the mountain. The report lasted from 1928 to 1931 [28].
The era of the 1950s to the 1960 s was a time of immigrant influx to Sebesi. The first migrant began to invite their relatives and neighbours migrating to Sebesi. Umbul began to turn into a hamlet in the 1960s, as new houses grew. During this period, there were three main hamlets, namely Tejang hamlet, Segenom hamlet, and Regahan Lada hamlet with a population of around 500 people.

In 1980, a village administrative was initiated in Sebesi and named as Desa Tejang, which included in the Kalianda sub-district. In 1985, with the help of the military, roads were built and connected from one hamlet to another. Furthermore, the port was repaired and enlarged as well as a scheduled public transport ship was formed. The local government also built supporting facilities, such as elementary school building and office for village staff. To fulfil the need of health services to its 800 inhabitants, the head village asked local government to send health workers to the island. It was only in 1992 that the Health Center was built. Subsequently, one midwife and one mantri were stationed there [29].

The existence of Anak Krakatau in 1930, which is included as the most active volcano in Indonesia and has erupted 40 times over 85 years, does not seem to be a threat to the community. They live side by side in peace with nature. The volcano activities of Anak Krakatau, such as rumbling sounds, small eruptions that emit smoke, the smell of sulfuric, and volcanic ash that splashed Sebesi, did not distract them. The routine activities of Sebesians take part in fading their memory of past disaster [30]. The people of Sebesi consider the volcanic activities of Anak Krakatau as harmless and routine phenomena hence they are courageous to keep on living there. The risk of explosion does not reflect as hazard that could create disaster.

\section{Tourism}

With an area of less than 3000 Hectare, Sebesi Island is included in the category of a small island. The significant characteristics of an island is its smallness and remoteness, which triggers vulnerability to natural hazards [31]. Furthermore, economically the main characteristics of islands are market, human and non-human resources limitation, hence their economic activities are less diversified and closely related to water, such as fisheries, interisland trade, and tourism. Similarly, Sebesi Island also rely on agriculture, fishing, and tourism [32].

Render to its natural environments, Sebesi island appointed as one of the leading marine tourism destinations by the South Lampung Regency. White sandy beach with its beautiful scenery and Mount Anak Krakatau on its direct opposite become main reason why Sebesi is promoted as tourism destination. The existence of Anak Krakatau proved to be a magnet for the development of tourism activities in Sebesi island. 
In 2008, the provincial government designated Sebesi Island as one of the Tourism Destination Objects (ODTW) in South Lampung Regency by offering marine ecotourism and adventure nature ecotourism. To support its tourism revenue, the Lampung government is also promoting an annual event entitled the Krakatau Festival. Confirmed through the Decree of the Governor of Lampung Number G/126/Diparda/1991, the Krakatau Festival was inaugurated as annual tourism activity for the Lampung Region. Various cultural events, fairs, and parades invigorate this activity, with the main pursuit was visiting Mount Anak Krakatau. This involved Sebesi island since the participants would stay overnight there and visit Mount Anak Krakatau in the next morning [33].

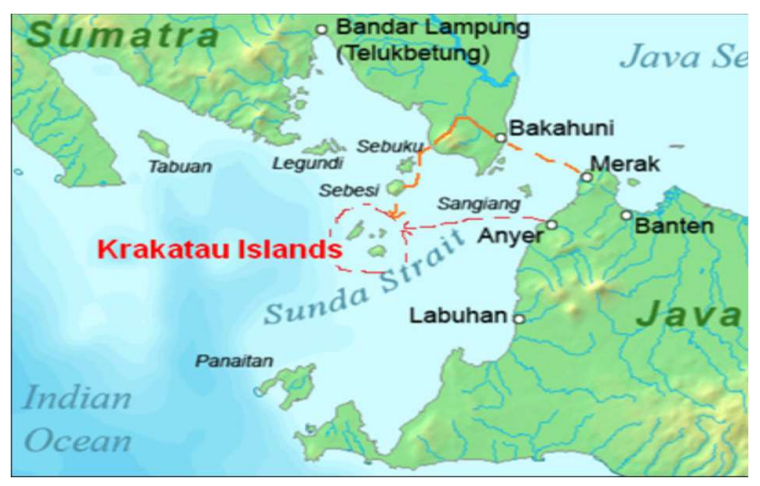

Fig 2. The Map of Festival Krakatau routes in 2016 onward.

Source: Evadianti, 2017 [34]

As a part of their lives, Anak Krakatau is also considered a blessing from God. According to Ibu Rumanah, Ibu Jamilah and Ibu Maemunah, at a grocery shop where they usually spend their afternoons, explained that Sebesi was their hope to fulfil their necessitates because Sebesi is a 'home' for them. Entering the year 2008 onwards, a wave of tourists both from local and foreign flooded Sebesi, especially when provincial government conducted Festival Krakatau. Accordingly, visitors who stayed at Sebesi could reach to a thousand people. Even at the time of the tsunami, several houses in Dusun I Bangunan were receiving about 30 guests from Jakarta [35].

Based on its historical background, the decision to select Sebesi Island as a tourist spot requires careful attention and planning from the government. Exposing Sebesi into tourist destination would lead people to gather round, hence preceded to the increasing vulnerability when a disaster occurs. Consequently, it requires awareness and preparedness in management both from local people, the government, and relevant stakeholders.

\subsection{The 2018 tsunami: a memory remind}

It is not easy for Jefrey (35 years) to live life as prior the tsunami since he was witnessing the enormity of the tsunami waves caused by the flank collapse of Anak Krakatau. He still clearly remembered that evening, he and 7 colleagues had been in the post for a week, assigned to control Anak Krakatau. He and four of his colleagues patrolled around the island, while two others stationed at the safeguard post on the island. The aim was to prevent the entry of fishermen to the island because of its alert status due to its rising volcanic activities. It seems that the common people are still not aware of the dangers of this mountain, so they still saw three fishing boats landing on the island. Indeed, this island is rich in crabs accordingly entice many fishermen try their luck hunting crabs on this island despite the dangers that lurk due to the lava and sulfuric fumes [36].

As the night was getting late, they saw 4 fishing boats docked on the island. They tried to chase these boats away by shining flashlights at the fishermen. From the distance, Jefry could see that these fishermen were lighting their stove. The fishermen looked relaxed and not at all frightened although Anak Krakatau erupted continually at that night. It was a full moon, and the sky was so clear that the sparks from Anak Krakatau could clearly be seen. According to Jeffry, one unusual view from Anak Krakatau that night was the black smoke from the fire that didn't leave the peak, where usually after the smoke came out it would immediately evaporate away from the peak. Furthermore, they saw the peak was in reddish and a flash like a path of fire on the seabed. Finally, the BKSDA patrol boat approached, not only dispel the fishermen but also to summon their colleagues who were on guard at the post. At that time, according to Jefry, the Captain felt something was wrong with Anak Krakatau, so he ordered all his crew to leave the guard post immediately and return to Sebesi although they supposed to return on the following [37].

It was at about 9 PM when the BKSDA ship slowly left the island, after driving away the fishermen. Unfortunately, of the four ships that docked, only one ship rushed to leave the island, while three ships stayed behind with the excuse of having dinner and would leave the island soon. The ship was just move further for no more than ten minutes, about 500 meters away from the island, when there was a loud bang, followed by rumbling and lightning that erupted from the peak of Anak Krakatau and debris that almost reached their ship. The debris rolled up three fishing boats that were docked and created very high waves. The ship's engine did not turn off but for some reason it could not run faster. The ship was running very slowly although there were high waves behind them, also to their right and left. Somehow it happened, the ship was moving very slowly but the waves were slowly 
disappeared without hitting the ship. Accompanied by the continuous azan from one of their comrades, the ship slowly made its way towards Sebesi. At that time, there was no signal so that they failed to contact their colleagues on Sebesi Island to inform the condition of Anak Krakatau and ask for help to pick them up.

After an hour away from Anak Krakatau headed to Sebesi, they started getting signals. One of Jefry's colleagues' telephones rang and informed them that there was a tsunami in Sebesi and asked for help from the BKSDA, whereas they were just about to ask for help from Sebesi's people. Hearing this news, Jefry's mind became increasingly frantic, remembering his wife and child who lived in Sebesi. Jefri is a native born in Sebesi, whose father is from West Nusa Tenggara and a mother is native born in Sebesi. They finally arrived safely in Sebesi. The trip, which usually only took two hours from Anak Krakatau to Sebesi, took nearly four hours. Arriving at Sebesi, they saw the Port was slightly destroyed by the tsunami and the atmosphere of the village was deserted. Upon information from his brother, Jefry immediately headed to Mount Sebesi, followed his wife and children and gathered with his extended family. The horror was not over yet because on Mount Sebesi, the roar sound of Anak Krakatau along with heavy rain continuously until morning came. The sound and rain are finally ceased as the morning came.

It is not easy for Jefri to forget this disastrous experience. Horrors often come every time he received assignment to monitor Anak Krakatau. In addition, every full moon after the tsunami, he still feels the fear of high waves. However, life must go on, and giving up his job at BKSDA is also unrealistic hence he decided to fight his fear by surrender to God.

Regarding the tsunami, when referring to Krakatau in 1883 , Jefry only remembers it vaguely. He never paid any attention to the story. Honestly, Jefry admits that he forgot about the incident, although he may have heard the story either from his parents or grandfather or even from the media or at school. For Jefry, the 2018 tsunami was the new disaster knowledge that was formed from personal experience [38].

While Jefry witnessed the eruption of Anak Krakatau, whose avalanche triggered a tsunami, people in several areas on Sebesi Island also experienced the horror of being hit by the tsunami waves. One of them is Nenek Kani (65 years old), a resident of Regahan Lada. When people screamed for the tsunami, nenek was still in her house, trying to get some clothes and some basic food. At that time, the first wave began to arrive which was more like a tidal wave that entered her house. Noticing water that enter the house, Nenek Kani, who lived alone, immediately left the house and walked towards Mount Sebesi, following the advice of the village head and the people around her [39].

On the way to the mountain, Nenek Kani saw the second wave that rolled up high and hauling 3 boats that were docked to the mainland and hit her house and her neighbours. With horror, Nenek Kani walk immediately toward the mountain. Due to her age, nenek Kani could not reach further to the top, hence she decided to stop at a high enough place with those who were not able to walk again. Nenek Kani subservient to God if indeed the waves would reach and rolled her in her shelter. Fortunately, the third wave was not as powerful as the second one, so her shelter was safe. It was the second wave that caused many houses destroyed in Regahan Lada hamlet.

In the following morning, Nenek Kani returned to her house. At that time, she saw so much garbage that entered the house and the right-side wall of her house was collapsed by the tsunami. Several houses to the right of her house were badly destroyed so could no longer be lived in. She preferred to return to the shelter for another night as she was afraid of another tsunami. Nenek Kani, who came to Sebesi in 1955, remembered that so long as she lives on Sebesi, this was her first experience, where it was the most terrifying disaster. Initially, she had never heard the word tsunami, just followed the words that people often said without understanding it. However, after the incident, she realized that the wave was called as tsunami. For nenek Kani, she never had experienced or heard any stories about the catastrophic disaster in Sebesi, including stories from her parents or grandparents. The tragedy of Krakatau in 1883 appears to have never recorded in the memory of this 65-year-old grandmother. Furthermore, Anak Krakatau to nenek Kani was nothing more than a volcano near the island of Sebesi.

Recalled to the 2018 tsunami, the people of Sebesi unlikely to believe that their island would strike by such a severe disaster. Throughout his life on Sebesi Island, Mr. Mochtar (currently around 70 years old) never imagined that he would suffer from the tsunami disaster. For him, Mount Anak Krakatau has become like God's creatures who live side by side with them. However, Mr. Mochtar is aware that the island they occupy has indeed experienced total destruction after the eruption of Krakatau in 1883. $\mathrm{He}$ still remembers the story told by his dato (grandfather) regarding the enormity of the eruption [40].

Andi (21 years old) and Hasmy (31 years old), like most other Sebesian youths, were relaxing at Tejang Pier. It was a full moon at that time, since it was Saturday night, many people were still relaxing around the pier, including the Head of the Dusun Bangunan, Mr. Achmad Kurtubi (40 years old), who was looking at the pier while relaxing. It was around 9PM, and suddenly the sea water receded for about ten meters, many small ships that were docked were 
immediately sunk because of the dry water. At that time, many fish were floundering on the dry sand, but the people on the pier did not dare to go down. The people in pier found this as a strange phenomenon and began to mumble about the tsunami in Aceh which began with low tide. It did not clear who was first shouted tsunami, but the people on the pier started screaming and ran to their hamlets to save themselves. Some people immediately fled to Mount Sebesi, but many also ran to their homes to save their families while telling other people. Instantly people panicked and flocked to Mount Sebesi to save themselves from the tsunami [41].

At that time, a group of tourists from Jakarta, about 30 people, were staying at Mr Hayun's homestay. They were very enthusiastic to see Anak Krakatau who was active because its reddish feature was an exciting phenomenon. After dinner, they plan to visit Gubuk Seng, an area where people can see the mountain clearly and where a monitoring tower belong to the South Lampung Regional Government stood. Luckily, these group had not yet left for the area due to the delay of dinner schedule, because the Gubuk Seng area was the worst place hit by the tsunami. These tourists together with local people immediately fled to Mount Sebesi and spent their night there [42].

Looking back on the tsunami disaster, Andi believes that it was the worst he has ever experienced, while he does not retain the story of Krakatau 1883 at all. As he remembers, neither his parents nor his grandparents ever told stories related to the 1883 tsunami disaster. It is rare for young Sebesi children to hear stories from their parents because their parents are busy with their plantation in the middle of the forest. In line with Andi, Hasmy also stated that he did not remember the story of Krakatau in 1883, except it was vaguely obtained through television or from social media. As far as Hasmy remembers, Hasmy's parents and grandparents never share stories to him, including about the 1883 Krakatau disaster. Differently, Kurtubi remembered the 1883 Krakatau story which he got from conversations with the elders in Sebesi, but the story was blurred due to the absence of a major disaster befall Sebesi.

Memory is an individual process whose abilities are limited. As an individual, a person is capable to remember the information obtained as well as to forget something he got earlier. Forgetting is the process of failing to recall existing information. Forgetting is also described as the loss of the ability to recall or reproduce previously learned knowledge. When the stored information is getting weaker, it will be difficult to retrieve it from storage, and it tends to get lost over time if the information is not used. This is called as the Decay theory. This is in line with Ebbinghaus' research which explains that there is a close relationship between forgetting and time. Important factors in forgetting are how the information obtained and how often the information repeatedly used. The less it is used, the more the memory fades and the longer the span of time, the more likely it is to be forgotten [43].

This is reflected to people in Sebesi where the 2018 tsunami believed as their first experience, although history records that a same type of disaster in a much larger scale have stricken. Some people, especially the older generation, still remember the story of the 1883 Krakatau eruption that triggered the tsunami, especially from the story of their dato or grandmother. However, the disaster gap, the rare occurrence of severe hazards during more than a century, is significant element in explaining the loss of disaster memory. Most of the other people forgot whether they had received stories or information related to the incident or not. However, for the younger generation of Sebesi, the information about the 1883 Krakatau disaster is mostly received either from schools or the media. Unfortunately, this information appeared easily replace by other information due to the infrequent repetition hence it was fading away.

Another reason why this devastated disaster was blurred among people in Sebesi is the fading of oral tradition practice from older to the current generation, either in the form of storytelling, lullaby, recite a poetry, or narrating legend. There are some efforts from tourism activists to create tell-tale tradition about Krakatau, but only to attract incoming tourists. Usually at night when these travellers get together, the guide would start to recount the story where this received positive response from them. Regrettably, this practice ceased to perform to local communities resulting in a total lack of civilian disaster awareness and preparedness, also diminishing cultural value in society.

The 2018 tsunami played important role for the Sebesians in recurring disaster memory. The disaster experience for the Sebesians led to the formation of specific attitude or behaviour in looking at their natural environment. The result of and combination on individual experience on 2018 tsunami initiate a collective memory for the communities since it confines and binds their most intimate remembrances to each other. It reminds them that they live in a hazardous environment. Therefore, this memory encourages the awareness attitude within the community. Currently, the Sebesian arranged themselves when they smell a strong sulfuric smell, or a sudden rain of ash, or a roar sound, as a sign that something is happening to Anak Krakatau. Furthermore, they also pay attention to the waves, its environs and believed that the safest place for evacuation is Mount Sebesi. Accordingly, what occurred in Sebesi is correspond to the concept of Halbwach's collective memory. Subsequently, preserving this shared memory, either in the form of 
storytelling, poetry recite, or stories, as well as children's songs are important ways to transmitting messages, to bring communities together, and maintain the historical ties. Thus, memories of the 2018 tsunami can last for several generations.
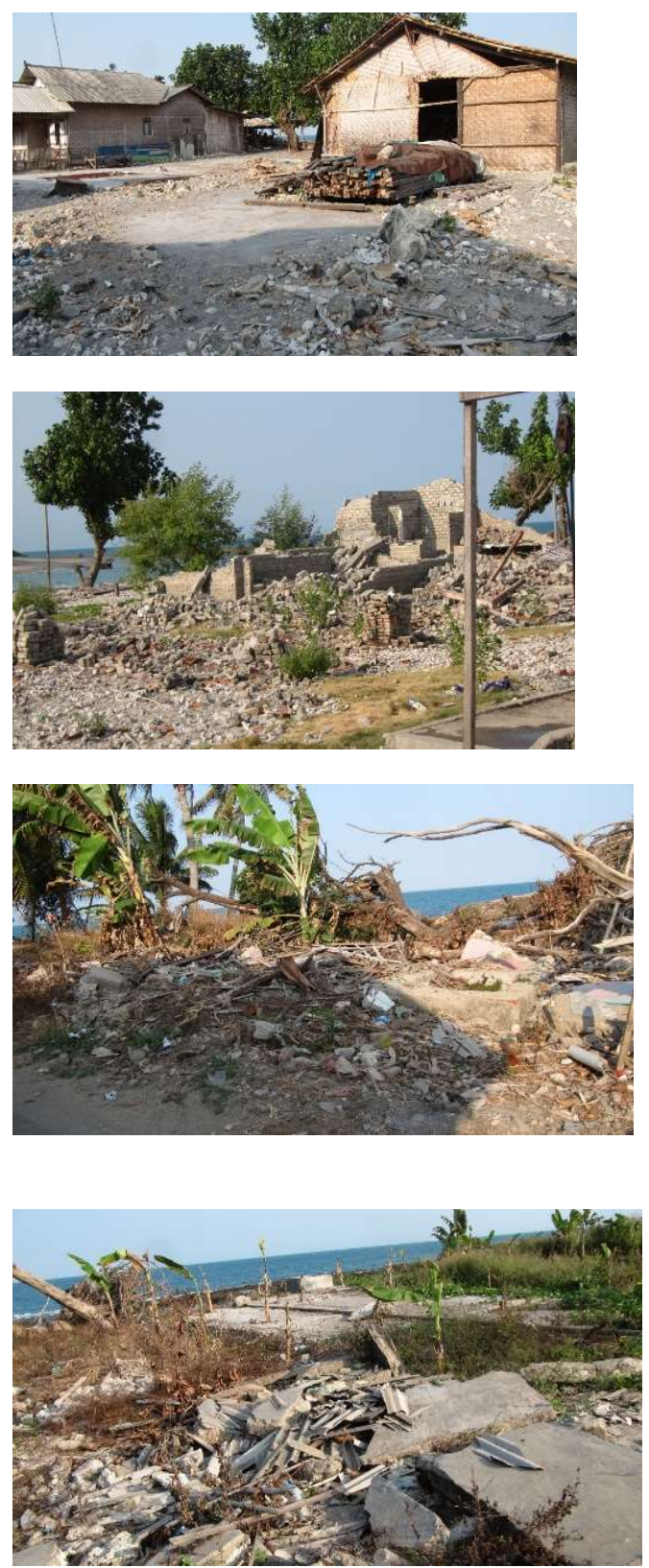

Fig. 3 the debris of houses in Regahan Lada and Teluk Baru due to 2018 tsunami.

Source: private collection taken on August 3, 2019

\subsection{The Cerita Smong as comparative case studies}

The Smong story (Cerita Smong) is a local knowledge that origins from Simeulue Island of Aceh. The story is about a very devastated event of Tsunami on 4 January 1907, which hit some areas of the island. The report from colonial archive mentioned that some areas in West Simeulue was damaged and many victims reported. However, due to the traumatic event of tsunami, survivors of tsunami were telling stories over generation and put messages that if there is a strong earthquake and retreating water on the shore, people should run to hills for evacuation purposes, and avoid the shore to collect fish, “...bila ada gempa kuat, laut surut maka larilah ke bukit dan jangan ke pantai untuk mengambil ikan...". That story has been transferred over generations, not only among native people of Simeulue, but also to migrants. During the Indian Ocean Tsunami of December 26, 2004, the tsunami was hit Simeulue with the similar preceeding like 4 January 1907 . There was evidence that many people warned again the smong stories and they successfully evacuated to the safe place. There were 7 people killed on the processes of evacuation, mostly because of panic and riding motorbike to evacuation areas. This event has made many peoples believed that knowledge of Smong safe people of Simeulue from tsunami.

However, there are different version related to how smong story transferred from one generation to other. The study sponsored by UNESCO conducted by LIPI in 2005 stated that smong stories transferred through story telling from older generation to their children, the grandchildren and so on. Usually, the time of storytelling related to its situation, mainly while there is natural hazard such as earthquake, floods and other. The elders would tell stories that hazard is not so dangerous compared to tsunami 1907. Another version says that elders or parents just telling stories without any particular situation, just tell story whenever they have chance to meet.

Other version about transfer story is through local folklore namely singing buai-buai (traditional lullaby) and narrating nandong (poem) [10], [11]. There are varies of lyrics depend on dialect of local dialect in Simeulue. However, those all shown that smong is part of local knowledge in Simuelue.

Report by UNESCO (Yogaswara and Yualianto, 2005)) stated that why smong stories has been existed over generation until the 2004's tsunami happened, because of several factors, namely (1) frequently of earthquake and other natural hazard that remind people about tsunami (smong) 1907 (2) survivors of tsunami 1907 that willing to telling stories and (3) kinship system and cultural bound among people of Simeulue and (4) material culture (natural and human made) that become 'living monument' remembering people about tsunami 1907. In addition, geographical features of Simeulue island that dominated of coastal and hilly areas provide people to monitor water situation after earthquake and easy access for evacuation route.

The tsunami of December 2004 that hit Simeulue island creating new knowledge about smong as local knowledge that safe people. The smong story has 
been researched by many agencies, including academic community, government agencies, international funding, and the like. The story of Smong transformed to different medium of expression, including digital tools and purposes for millennial generation. Indeed, the smong story be part of policy making of qanun related to disaster education, The story of Smong will always in mind of the people in Simeulue and Aceh.

\section{Conclusion}

History records the rise and fall of the Sebesi island due to a catastrophic disaster. The eruption of Krakatau on August $27^{\text {th }}, 1883$ has led to enormous tsunami and took life of all the people in Sebesi. Based on the report from the officers who visited Sebesi after the eruption, it is unlikely to have survivors of this disaster. Therefore, the people living today are not those who witnessed or survived from the severe disaster. The current society is a migrant community who arrived in Sebesi to seek their chance from the development of agriculture. The fertile plantations cannot be separated from Krakatau's "blessing" because the volcanic ash that buried Sebesi has proven to make the land on this island very fertile.

The birth of Anak Krakatau since 1930 were a new challenge for newly established settlement in Sebesi. However, the economic reason was their main motivation to stay, greater than the threat of an unknown danger. Over time, Sebesi has become home to more than two thousand people. The growing of Anak Krakatau brought piece of good fortune to them, namely the development of tourism, which is economically profitable. The threat of danger viewed as just a figment since Anak Krakatau is so calm and pampers the Sebesians with the beauty of its evolution and its abundant marine life.

The rare occurrence of severe disaster from post Krakatau in 1883 to 2017 has caused people in Sebesi unaware to their 'risky' environment. The continuous eruption of Anak Krakatau, from booms, rain of ash, to the strong smell of sulfuric acid are believed as normal and harmless by the Sebesians. The disaster gap, different perceptions in looking at Anak Krakatau, as well as social, economic, and cultural life, are significant element in explaining the loss of disaster information they learnt from elders. Additionally, the absence of oral tradition practices, in the form of storytelling, lullaby, poetry and others led to the loss of disasters memories in current generations. Even though local government is regularly celebrating annual commemoration of Krakatau eruption (Festival Krakatau), but this does not generate awareness and disaster risk reduction of the communities in Sebesi increase. It seems there is memory distance between Sebesi people with people in mainland Lampung area and Banten coast area.
However, tsunami-related knowledge among young people in Sebesi mostly been formed by learning at school and from the media. It was only after the Aceh Tsunami in 2004 that the public became familiar with the word tsunami due to the very intensive media coverage. In the past, people were more familiar with rajuh or known as rising tide into the land. Subsequently, the condition in Sebesi confirmed with the concept of cultural memory where the media plays an important role in shaping memories and further regulating people's behaviour.

The power of nature once again revealed when Anak Krakatau initiate a tsunami that strike Sebesi island, the coast of South Lampung, as well as Anyer and Pandeglang on December 22, 2018. The disastrous has changes the way in which the Sebesians perceived Anak Krakatau, from a blessing to a thread. The Sebesians are currently responsive to their surrounding environment, hence the hidden blessing of this disaster is the re-establishment of disaster memories and the revival of disaster awareness and preparedness. Lesson to learn from the Smong story of Simeulue is that a cultural preservation needs to be consider through appreciation for local people who maintain their knowledge. Local knowledge is always changing due to socio-cultural change in the community. However, recognize the local knowledge is the best way to acknowledge that local people owned their knowledge, not only scientist or the government.

\section{References}

1. "Tsunami Selat Sunda: Korban Tewas 430 orang, Krakatau jadi 'siaga', Hujan Abu di beberapa tempat", 27-12-2018. Diakses pada https://www.bbc.com/indonesia/live/indonesia $-46663949$

2. "BMKG Paparkan Kronologi Tsunami Selat Sunda", 23-12-2018 diakses dari https://www.cnnindonesia.com/teknologi/201 81231002758-199-357400/bmkg-paparkankronologi-tsunami-selat-sunda

3. Zengefinnen, T., Lovhort, F., Pedersen, G.K., Muhari, Abdul. "Modelling 2018 Anak Krakatoa Flank Collapse and Tsunami: Effect of Landslide Failure Mechanism and Dynamics on Tsunami Generation." Pure and Applied Geophysics (2020): 2493-2516

4. Interview by phone with Bapak Hayun, a member of Tourism activist in Sebesi island, on 30 June 2020, at 19.30 WIB.

5. Interview with Bapak Andi (staff of Desa Tejang) on 3 August 2019 in the Office of Tejang Village in Sebesi island.

6. Simon Winchester, S. Krakatau: Ketika Dunia Meledak 27 Agustus 1883 (Terjemahan) (Jakarta: Serambi Ilmu Semesta, 2006). 
7. Yogaswara, H., Yulianto, E. Smong-Local Knowledge and Strategies on Tsunami preparedness in Simeulue Island, Nanggroe Aceh Darussalam, (LIPI and UNESCO, 2005).

8. Bankoff, G. "Comparing Vulnerabilities: Toward Charting an Historical Trajectory of Disasters," in Historical Social Research. Vol. 32, No. 3 (212), (2007) pp. 103-114.

9. Halbwachs, M. On Collective Memory. Chicago: The University of Chicago Press, (1992).

10. Tulius, J. (2020). "Lesson from The Past, Knowledge for The Future: Roles of Human Memories in Earthquake and Tsunami Narratives in Mentawai, Indonesia." Paradigma Jurnal Kajian Budaya, , Vol 10 (2), (2020).

11. Rahman. A., Sakurai.A., Munadi, K. 'Indigenous Knowledge management to Enhance Community Resilience to Tsunami Risk: Lesson Learned from Smong Traditions in Simeulue Island, Indonesia.' in IOP Conference Series Earth and Environmental Science. 56((1): 012018. IOP Publishing: 2017.

12. Gani A, Jaelani, "Seberapa Panjang Longue Durée? Catatan tentang Longue Durée dalam Praktik Penulisan Sejarah," in Metahumaniora, Volume 9 Nomor 3, Desember 2019, 313 - 327

13. Interview with Bapak Rozali-secretary of Tejang Village term 2020 - on 15 October 2020 and interview with Bapak Tb. Firdaussecretary of Tejang Village term 2021-2023 on 14 April 202

14. Wiryawan, B., D.G. Bengen, I. Yulianto, H.A. Susanto, A.K. Mahi, M. Ahmad. Sumberdaya Pulau Sebesi, Kecamatan Rajabasa Kabupaten Lampung Selatan. (Penerbitan Khusus Proyek Pesisir, Coastal Resources Centre - University of Rhode Island. Narraganset, Rhode Island, 2002)

15. Nieuwe Hoornsche Courant, Friday 29 January 1937.

16. Soerabaijasch Handelsblad, 22 October 1833;

17. Algeemen Handelsblad, 22 November 1833;

18. De Standaard, 4 December 1883.

19. “Een Bezoek aan Krakatau,” De Locomotief, 17 Maart 1885.

20. J.W Van Royen, "Nota Over de Lampongsche Merga's" (Landsdrukerij, 1930, pp. 49)

21. Twee Eilanden in Straat Soenda Te Koop," De Locomotief, Zaterdag 22 Augustus 1936, Zesde Blad, p. 2.

22. De Sumatra Post, 27 Augustus 1936, “Adat Rechten en Legenden”, Derde Blad.

23. Ian Thorton, Island Colonization. The Origin and Development of Island Communities. Cambridge: Cambridge University Press, 2002
24. Interview with Bapak Busry on 15 October 2020 at Dusun Segenom. He was a supervisor for Segenom area. He was born in 1947 in Sebesi island and became $4^{\text {th }}$ generation of his families that stayed in the island. In 1955, his father, who also a supervpervisor in Segenom, and his fellow supervisor from Regahan Lada, Mad Husein, were able to conduct Hajj pilgrim because of coconut sales during that period. Bapak Busry is a son of Hadji Abdoellah, a first supervisor appointed by Hadji Djamaloedin in 1925. He was among the first settler in Sebesi.

25. Interview with Bapak Busry on 15 October 2020; interview with Ibu Rohani on 16 April 2021; interview with Dato Mohamad Saleh (Saleh Salui) on 15 April 2021; Interview with nenek Kani on 25 May 2021

26. Interview with Bapak Hayun during field research in 2020 and 2021.

27. Interview with Bapak Mochtar on 17 April 2021 and 25 May 2021. His Dato (kakek) was the first batch workers that granted permission from Saleh Ali as profit-sharing cultivators in 1937. This was proved by a copy of an agreement letter between his Dato and Saleh Ali.

28. ANRI, 8552 TZG Ag 1931/29051

29. Interview with Bapak Mochtar on 23/5/2021, $17 / 4 / 2021$, and 14/10/2020. He was appointed as Head Village for the period from 19882000.

30. Syamsidik, Benazir, Mumtaz Luthfi, Anawat Suppasri, and Louise K. Comfort, "The 22 December 2018 Mount Anak Krakatau volcanogenic tsunami on Sunda Strait coasts, Indonesia: tsunami and damage characteristics" in Natural Hazards and Earth System Sciences, (20, 549-565, 2020).

31. Lewis, James. (2009). "An Island Characteristic: Derivative Vulnerabilities to indigenous and exogenous Hazards." Shima: The International Journal of Research into Island Cultures, (Vol 3: 1).

32. Jedrusik, "Island Studies. Island Geography. But What is an Island?" in Miscellania Geographica, (Volume 15(1):201-212, 2011).

33. Yuli Evadiyanti, "Reposisi Brand dalam Festival Krakatau oleh Dinas Kebudayaan dan Pariwisata Kota Lampung." PRofesi Humas: Jurnal Ilmiah Ilmu Hubungan Masyarakat, (Vol 2: No. 1, 2017).

34. Yuli Evadianti, ibid

35. Interview with Ibu Rumanah, Ibu Jamilah, and Ibu Maemunah at the grocery store belong to Ibu Rumanah on 13 October 2020 at 14.00 PM

36. Interview with Bapak Jefry on 22 May 2021. He is a staf in BKSDA since 2008.

37. Interview with Bapak Jefry on 22 May 2021 
38. Different with Pak Jefry, Bapak Herman, his elder brother from different mother, still clearly remember the catastrophic tsunami Krakatau because his grandmother from his mother's side continuously told the story to him. Bapak Herman works as a ship crew in KM Dewi Putri, a ship in Canti-Sebesi line. The experience of Bapak Herman explain that some Sebesians might know and still remember the previous tsunami, although most of them fairly admitted that they forgot about a devastated disaster in 1883. Bapak Herman, personal communication, 21 May 2021.

39. Interview with nenek Kani on 25 May 2021. She was among the first settler who moved in to Sebesi in 1955 at the age of 10 years old, the age where she can clearly remember her journey to Sebesi and the development of her umbul into hamlet. She was a wife of Mad Huein, a supervisor of Regahan Lada hamlet, so that she knew a development of this hamlet from 1960 s to 1990 s. Until recently, nenek Kani is an honourable figure as healer and traditional mid-wives.

40. Interview with Bapak Mochtar on 14 October 2020.

41. Interview with Hasmy, Andi, and Bapak Achmad Khurtubi di separate place during field research on 13-16 October 2020.

42. [Interview with pak Hayun during field research on 13-16 October 2020.

43. Nirupma Rath, "Remembering and Forgetting," in Psychology of Education (New Delhi: Global Vision Publishing House, 2008) 